\title{
Moralitas Kebaikan dan Kesalehan di Seputar Tubuh dan Pakaian dalam Ruang Media Sosial
}

\author{
Puji Rianto \\ Program Studi Ilmu Komunikasi, Universitas Islam Indonesia \\ Jl. Kaliurang KM. 14,5 Sleman, Yogyakarta 55584, Indonesia \\ Corresponding author: puji.rianto@uii.ac.id
}

\begin{abstract}
This study examines the discourse of morality centered around the body and clothing in the social media space. The research uses a qualitative approach. Data was collected using a netnographic strategy in which all uploads on social media in the form of writing, photos, videos even emoticons were considered as data. The analysis uses the approach of Paula Saukko who sees the text cannot be separated from its context. By analyzing the uploads and comments on Salmafina's Instagram page, this research shows that uploading photos of Salmafina in a bikini have sparked a discourse on morality around the body and clothes. The discourse can be seen from the assessments of Salmafina's personality, and considers good or bad, whether Salmafina is pious or not based on the clothes she wore. The assessment also places Salmafina as the other. The discourse on morality around the body and clothing cannot be separated from its context, namely post-New Order liberalization, the excitement of Islam and the role of religion in society, as well as the widespread use of social media. Keywords: Dress; Good-Bad; Morality; Other; Piety
\end{abstract}

\begin{abstract}
Abstrak
Penelitian ini mengkaji wacana moralitas yang berpusat di sekitar tubuh dan pakaian di ruang media sosial. Penelitian menggunakan pendekatan kualitatif. Data dikumpulkan dengan menggunakan strategi netnografi di mana semua unggahan di media sosial dalam bentuk tulisan, foto, video dan bahkan emoticon dianggap sebagai data. Analisis menggunakan pendekatan Paula Saukko yang melihat teks tidak terlepas dari konteksnya. Dengan menganalisis unggahan dan komentar pada laman Instagram Salmafina, ini penelitian menunjukkan bahwa unggahan foto Salmafina dengan bikini telah memantik wacana moralitas di sekitar tubuh dan pakaian. Wacana itu dapat dilihat dari penilaian-penilaian terhadap pribadi Salmafina, dan menganggap baik buruk, shaleh tidaknya Salmafina berdasar pada pakaian yang digunakan. Wacana moralitas di sekitar tubuh dan pakaian tersebut tidak dapat dilepaskan dari konteksnya, yakni liberalisasi pasca-Orde Baru, kegairahan Islam dan peran agama dalam masyarakat, serta meluasnya penggunaan media sosial. Kata kunci: Baik-Buruk; Keshalehan; Liyan; Moralitas; Pakaian
\end{abstract}

\section{Pendahuluan}

Pada awal-awal studi media, isu di seputar moralitas biasanya dikaji dalam terminologi "moral-panic" (Furedi, 2016; Lacey, 2002; Tester, 1994) yang umumnya menunjuk pada dampak negatif atas kehadiran media. Media ditempatkan sebagai faktor penyebab bagi meluasnya perilaku buruk di masyarakat, utamanya anak muda. Kajian Cohn, misalnya, sebagai salah satu penelitian awal yang menaruh perhatian pada isu moralitas didasari keprihatinan atas kehadiran media massa, terutama film, atas dampak-dampak buruknya bagi masyarakat.

Di Inggris, munculnya "panik moral" ditujukan terutama untuk merespon kelahiran beragam budaya anak muda (youth culture) yang didefinisikan sebagai menyimpang dan nakal (Tester, 1994). Hall et al (1978) dalam Policing the Crisis mengkaji mengapa tindakan kriminal menjambret senantiasa diasosiasikan dengan praktik-praktik yang dilakukan oleh anak muda kulit hitam, dan bagaimana krisis yang mengitari atau menjadi konteks dari kejahatan menjambret dapat dianggap sebagai representasi dari krisis yang lebih luas terkait dengan legitimasi dan hegemoni negara Inggris (Tester, 1994).

"Panik moral" dihasilkan oleh media dan kelompok-kelompok kepentingan yang disebut sebagai "moral entrepreneurs". Kelompok ini menggunakan media untuk menggemakan perhatian mereka, dan media merespon baik dengan memberi mereka ruang di media 
(Hunt, 1997). Media juga menggemakan panik moral melalui berita dan artikel-artikel yang menyuarakan kondisi tidak baik di kalangan masyarakat, dan biasanya berkisar di seputar kehadiran teknologi media baru. Dalam hal ini, media dianggap sebagai ancaman terhadap tatanan moral (Furedi, 2016).

Dalam masyarakat, "panik moral" telah menjadi bagian dari pertarungan wacana untuk mendefinisikan mana yang baik dan buruk, mana yang boleh dan tidak boleh. Wacana moralitas karenanya sering kali digunakan untuk mendisiplinkan publik (Pamungkas, 2018) ketika telah dikonstruksikan sebagai moralitas publik. Dalam pengertian umum, moralitas publik mempunyai dua pengertian (Pamungkas, 2018). Pertama, merujuk pada standar moral atau etis yang ditujukan kepada masyarakat. Kedua, moralitas publik juga dapat dimaknai sebagai suatu bentuk tekanan sosial yang ditujukan untuk mendominasi standar moral dalam masyarakat dan bentuk-bentuk kedisiplinan dan kepatuhan publik sebagai respon atas "panik moral".

Di Indonesia, wacana atau kelompokkelompok "moral entrepreneurs" ini timbultenggelam, tapi dalam situasi-situasi tertentu muncul dalam skala luas dan penuh ketegangan. Kelompok-kelompok "moral entrepreneurs” ini seringkali memaksakan pandangan-pandangan mereka untuk dijadikan sebagai standar moral publik. Pamungkas (Pamungkas, 2018), misalnya, menunjukkan bahwa jauh sebelum Undang-Undang Pornografi disahkan wacana mengenai pornografi dan pornoaksi telah dikonstruksi dalam beragam media dan saluransaluran dakwah. Panik moral karenanya tidak lagi semata konsekuensi sosial, tapi juga menjadi bagian dari kepentingan yang bersifat politis.

Wacana moralitas hampir selalu menimbulkan kontroversi dan pertarungan beragam kelompok karena menyangkut definisi baik-buruk. Moralitas mencakup pengertian baik- buruknya tindakan manusia. Moralitas karenanya merujuk pada seperangkat peraturan atau standar sosial yang mengatur tingkah orang-orang dalam suatu kebudayaan tertentu (Haris, 2019: 85). Kebudayaan tidak pernah tunggal, maka wacana di seputar moralitas juga tidak pernah seragam. Kebudayaan bahkan menjadi ruang pertarungan kekuasaan atau "perang kebudayaan" (Eagleton, 2016) sehingga wacana-wacana moralitas pun seringkali bersaing satu dengan lainnya.

Setiap orang mempunyai dasar moralitas. Moralitas seseorang adalah seperangkat keyakinan moral yang dianggap baik dan buruk, dan merupakan standar yang digunakan untuk memutuskan suatu tindakan (Haris, 2019: 85). Kepercayaan ini dapat berasal dari beragam sumber dalam masyarakat, termasuk agama. Setiap tindakan ketika berhubungan dengan adaptasi intuisi moral menjadi domain moral (Prabhu et al., 2020). Ada lima domain moral yang aktif, yakni yang berhubungan dengan kepedulian (care), keadilan (berhubungan dengan kesetaraan dan distribusi), loyalitas kelompok (berhubungan dengan penghormatan dan kesetiaan kelompok), otoritas (penghormatan terhadap tatanan sosial, kepemimpinan dan hirarki otoritas yang sah, dan ketaatan), pemurniaan (berhubungan usaha menekan sifat duniawi manusia dan mengembangkan pola pikir spiritual) (Prabhu et al., 2020: 256-257).

Kehadiran media sosial membuat wacana moralitas tidak lagi semata didominasi oleh para “moral entrepreneurs". Sebaliknya, setiap pengguna (user), istilah yang lebih tepat dibandingkan dengan audience (Lister et al., 2009), mempunyai kemampuan untuk menyuarakan moralitas berdasarkan fondasi moral mereka. Ini karena media sosial dicirikan oleh sifatnya yang partisipatif (Nasrullah, 2017). Dalam kaitan ini, media sosial hadir sebagai medium yang paling mudah dan cepat untuk mengirimkan dan mengkonsumsi informasi dalam bentuk teks, gambar, dan juga video (Hayes \& Kelly, 2018). 
Dijk (Nasrullah, 2017) mengemukakan bahwa media sosial adalah platform media yang memfokuskan pada eksistensi pengguna yang memfasilitasi mereka dalam beraktivitas ataupun berkolaborasi. Dalam konteks ini, media sosial dapat dilihat sebagai medium online yang menguatkan hubungan antarpengguna sekaligus menjalin ikatan sosial. Media sosial juga menjadi medium untuk pengungkapan diri (Prihantoro et al., 2020).

Sejak studi Cohn dan Hall, ada banyak studi lainnya yang telah dikerjakan. Beberapa studi melanjutkan argumen Cohn mengenai moral panik yang dihasilkan oleh media digital (Walsh, 2020) dan smartphone (Rao \& Lingam, 2020), sedangkan lainnya melihat hubungan yang saling mempengaruhi antara moralitas khalayak dengan konten media (Prabhu et al., 2020; Tamborini et al., 2013, Corpus, 2015)

Studi Walsh dan Rao dan Lingam menggunakan perspektif yang sama dengan menaruh perhatian pada dampak-dampak negatif yang ditimbulkan oleh kehadiran media baru dan digital. Studi ini berangkat dari tradisi transmisi, dan melihat khalayak sebagai agen pasif. Studi dengan menggunakan pendekatan ini meskipun menarik karena memberikan gambaran tentang dampak media, tapi mengandung kelemahan karena dampak-dampak khalayak dianggap seragam (Baran \& Davis, 2010).

Studi Prabhu et al dan Tamoborini et al berbagi perspektif yang sama dalam mengkaji moralitas di media. Kedua penelitian itu menggunakan perspektif Model of Intuitive Morality and Exsemplars (MIME), suatu perspektif yang melihat hubungan-hubungan di antara konten media dan moralitas khalayak. Kedua studi ini menunjukkan bahwa media dapat mengaktifkan intuisi moral penonton, dan moralitas penonton menentukan bentuk-bentuk konten media yang menjadi pokok perhatian mereka (Prabhu et al., 2020; Tamborini et al., 2013).
Studi mengenai moralitas yang dihubungkan dengan praktik media sosial dilakukan oleh Venäläinen dan Virki (Venäläinen \& Virkki, 2019). Kedua peneliti ini mengkaji percakapan di media daring mengenai kekerasan yang dilakukan oleh perempuan Finlandia dan migran laki-laki non kulit putih. Dengan perspektif sosiologi nilai, penelitian menggambarkan bahwa diskusi tersebut menjadi ruang bagi perebutan nilai-nilai moral yang dicirikan oleh laki-laki dan berkulit putih.

Dari keseluruhan penelitian di atas, belum ada penelitian yang berusaha menginvestigasi wacana moralitas di media sosial, terutama di Indonesia. Padahal, pengguna media sosial di Indonesia mencapai 170 juta atau 61,8 persen data menurut Hootsuite pada Januari 2021 (Rizal, 2021). Beberapa studi mengenai media sosial di Indonesia biasanya dihubungkan dengan etika (Mahanani, 2017, Rianto, 2020) dan hoax (Sosiawan \& Wibowo, 2020). Penelitian yang dihubungkan dengan bagaimana unggahan seseorang memancing wacana moralitas, yakni penilaian atas baik-buruk pribadi seseorang belum pernah dikaji. Untuk mengisi celah atau kekosongan tersebut, penelitian ini mengeksplorasi wacana moralitas di media sosial yang dihubungkan dengan pakaian dan tubuh dengan mengambil kasus Salmafina. Dengan kata lain, komentar-komentar di media sosial berhubungan dengan suatu wacana mengenai moralitas tertentu yang berpusat di sekitar tubuh dan pakaian. Dengan mengkaji wacana moralitas di sekitar pakaian dan tubuh dan menghubungkannya dengan konteks yang memediasi wacana tersebut, penelitian ini diharapkan menyumbangkan penelitian tekstual-netnografi yang masih jarang dilakukan. Secara praktis, penelitian ini diharapkan dapat mendorong refleksi kritis yang lebih luas di antara para pengguna media sosial ketika memberikan komentar atas subjek unggahan terutama ketika komentar itu mengandung dimensi moralitas, yakni menyangkut baikburuk pribadi subjek atau benar salah atas tindakan-tindakan yang dilakukan oleh subjek. 


\section{Metode Penelitian}

Penelitian ini menggunakan pendekatan kualitatif dengan strategi netnografi atau etnografi lain. Lazimnya penelitian kualitatif, penelitian ini fokus pada deskripsi mendalam atas fenomena yang dikaji dengan mendasarkan pada kata-kata dan bukannya data statistik (Sugiyono dan Lestari, 2021) sehingga konteks menjadi sangat penting.

Dalam penelitian netnografi, seluruh unggahan pengguna baik dalam bentuk teks (tulisan), gambar ataupun video dianggap sebagai data (Kozinetz, 2010). Data dikumpulkan dengan cara tembakan langsung (schreenshot) atas unggahan dan komentar pengguna di Instagram Salmafina. Rentang waktu unggahan dikumpulkan sejak Juli 2019 hingga Oktober 2020. Ada kurang lebih 90 data tembakan langsung di Instagram Salmafina yang berhasil dikumpulkan, dan secara khusus berhubungan dengan komentar-komentar yang dihubungkan dengan wacana moralitas. Untuk lebih mendalami kasus, peneliti juga menjadi follower Instagram Salmafina.

Salmafina dijadikan subjek penelitian karena tiga alasan. Pertama, Salmafina dapat dikategorikan sebagai mikro-selebritis yang terkenal melalui Instagram sehingga tingkah lakunya akan mendapatkan banyak sorotan publik. Kedua, pilihannya berpindah agama dari penganut Islam untuk berpindah agama lain. Ketiga, perpindahan itu diikuti dengan melepas kebiasaannya menggunakan jilbab sehingga menarik banyak komentar di media sosial, terutama yang dihubungkan baik-buruknya kepribadian Salmafina.

Data dianalisis dengan mengikuti pandangan (Saukko, 2003) di mana realitas kehidupan akan ditentukan oleh mediasi wacana dan struktur/konteks sosial. Analisis karenanya akan memfokuskan pada tiga wilayah, yakni komentar atau tanggapan para pengguna terhadap unggahan foto Salmafina Sunan (teks tanggapan itu sendiri adalah discourse), wacana (discourse) yang memediasi tanggapan-tanggapan itu yang akan dicari dari kata-kata kunci untuk ditarik ke wacana yang memediasinya, dan yang terakhir melihat konteks kemunculan wacana tersebut.

Pada tahap awal, data yang telah dikumpulkan dalam bentuk tembakan langsung (schreenshot) akan dipilah-pilah untuk menentukan mana unggahan yang mengandung dimensi moralitas dan mana yang tidak. Ukurannya adalah apakah unggahan atau komentar itu mengandung penilaian baik-buruk ataupun benar-salah ataukah tidak. Ini karena moralitas pertamapertama berhubungan dengan baik-buruk.

Tahap berikutnya adalah mencermati wacana-wacana yang berkembang dalam unggahan atau komentar yang mengandung dimensi moralitas. Wacana-wacana itu kemudian dikategorisaikan ke dalam berbagai tipe wacana. Tahap ketiga, mencari konteks yang lebih luas dari setiap wacana yang muncul. Dengan cara ini, diharapkan akan membawa penelitian ini pada prinsip-prinsip polyvocality yang disarankan Saukko (Saukko, 2011). Penelitian ini karenanya juga mempertimbangkan komentar yang didasarkan jenis kelamin (pria dan wanita), agama (Islam, Nasrani, Hindu atau Budha atau lainnya sejauh ditemukan), serta dengan usia (sejauh bisa diidentifikasi).

Penelitian ini berbasis media sosial, peneliti menyadari bahwa latar belakang para pengguna sebagaimana disebutkan di atas tidak dapat dijamin seratus persen valid. Ini karena kebenaran identitas seseorang di media sosial dapat saja benar, tapi bisa juga identitas lainnya ("second" atau "third identity"). "Ketidakhadiran" riil para pengguna media sosial bagaimanapun mempengaruhi identitasidentitas yang ditampilkan para pengguna. Meskipun demikian, wacana yang berkembang dalam kaitannya dengan cara berpakaian Salmafina dan relasinya dengan moralitas dapat dianggap valid berdasarkan argumen bahwa wacana yang mereka munculkan memiliki cantolannya dalam wacana sosial yang lebih luas. 


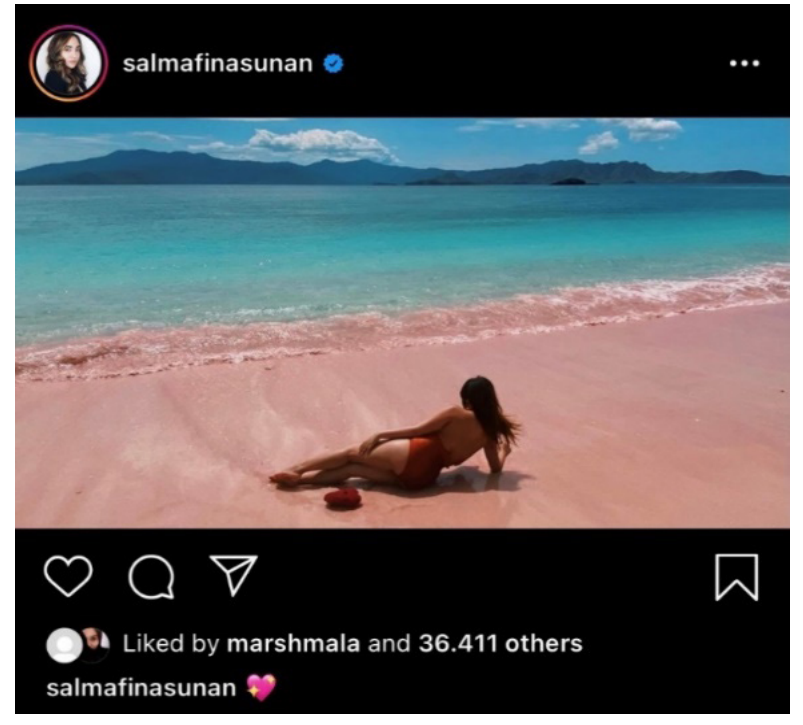

Gambar 1. Unggahan Bikini Salmafina Sunan. Foto diunggah pada 19 Agustus 2020.

Sumber: Komentar di Instagram Salmafinasunan (2020)

\section{Hasil Penelitian dan Pembahasan}

Penelitian ini berfokus pada unggahan foto Salmafina di Instagram-nya, dan komentarkomentar para pengguna. Unggahan foto Salmafina ketika menggunakan bikini di sebuah pantai di Bali telah memancing ratusan komentar hanya dalam beberapa jam, dan menyulut "intuisi moralitas" para pengguna. Penilaian-penilaian moral itu tidak berhenti pada Salmafina sebagai pribadi yang baik ataukah tidak (penilaian baik-buruk), tapi berimplikasi pula pada pandangan bahwa suatu tindakan dapat dibenarkan ataukah tidak.

Uraian selanjutnya memaparkan beberapa soal mengenai pertarungan berbagai wacana moralitas dalam kasus Salmafina. Pada waktu bersamaan, mengidentikasi moralitas apa saja yang berusaha dimunculkan oleh para komentator di media sosial tersebut.

Penelitian ini lebih cenderung menggunakan komentator atau pengguna (users) dibandingkan dengan netizen karena kasus yang diangkat tidak memiliki atau memiliki hubungan lemah terhadap isu-isu publik yang dihubungkan dengan kewarganegaraan. Penggunaan kata

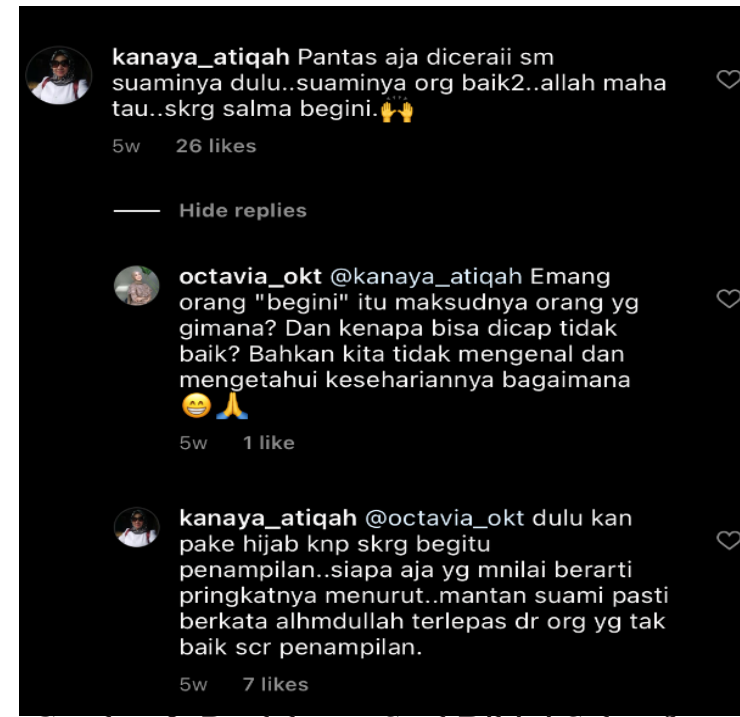

Gambar 2. Perdebatan Soal Bikini Salmafina

Sumber: komentar di Instagram Salmafinasunan (2020)

pengguna atau komentator karenanya lebih tepat dibandingkan dengan netizen (kewargaan digital). Penggunaan komentator media sosial juga lebih pas karena merefleksikan suatu budaya lisan yang lebih menonjol di Indonesia.

Pada Gambar 1, Salmafina mengunggah fotonya yang menggunakan bikini dengan pose membelakangi kamera. Foto yang diunggah pada 19 Agustus 2020 tersebut disukai oleh 37.707 pengguna dan mendapatkan 1.759 komentar. Dari unggahan foto bikini inilah, perdebatan dan komentar antara para pengguna Instagram dimulai dan menyentuh hal-hal yang bersifat transenden (agama). Komentarkomentar ini dikategorikan ke dalam persoalan moral atau moralitas karena komentar-komentar itu syarat dengan penilaian baik-buruk, benarsalah dan bahkan shaleh-tidak shaleh. Secara hakiki, ini menyangkut penilaian terhadap Salmafina sebagai manusia. Dalam hal ini, bermoral tidaknya Salmafina atau baik buruknya pribadi Salmafina bersandar pada pakaian yang digunakan. Kata-kata "sekarang salma begini" dari salah seorang komentator (Gambar 2) merujuk pada pakaian yang dikenakannya, yakni 


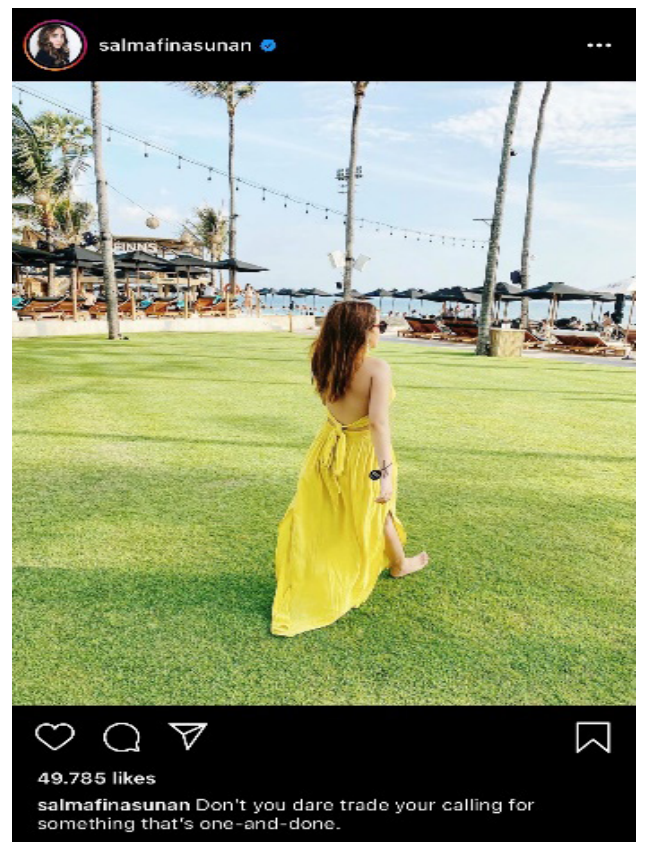

Gambar 3. Unggahan Salmaafina pada 24 Oktober 2019

Sumber: Komentar di Instagram Salmafinasunan (2020)

bikini (Gambar 1). Secara konotatif, komentar ini hendak mengatakan bahwa Salmafina bukanlah pribadi yang baik karena menggunggah foto ketika dirinya sedang menggunakan bikini. Di sini, konteks di mana bikini itu digunakan tidak lagi menjadi penting karena pokok perhatian pada foto bikini yang diunggah sehingga awalnya foto tersebut bersifat privat atau lokal karena di pantai menjadi lebih terbuka, dan dapat dikonsumsi oleh publik. Bikini lantas dirujuk sebagai representasi dari ketidakshalehan Salmafina.

Wacana agama sangat kuat sebagai rujukan atas penilaian moralitas para penngguna terhadap cara berpakaian Salmafina. Ini bisa dilihat dari komentar kanaya_atikah ketika menanggapi akun octavia_okt yang menggugat maksud perkataan kanaya_atikah yang dinilainya menghakimi (Gambar 2). Masalah yang menjadi pokok perdebatan adalah sebelumnya Salmafina menggunakan hijab, tapi sekarang bukan saja melepas hijabnya, tapi mengunggah foto dirinya menggunakan bikini. Di sini, moralitas agama secara jelas menjadi sarana dan sekaligus

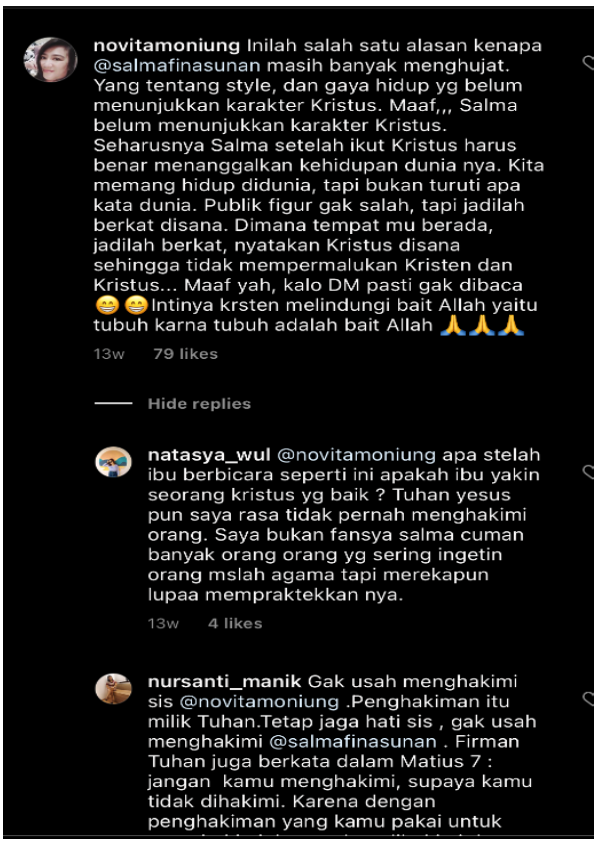

Gambar 4. Komentar pengguna NonMuslim Sumber: Komentar di Instagram Salmafinasunan (2020)

dasar pijakan untuk menilai [bikini] Salmafina. Dalam wacana agama, pakaian perempuan (dalam Islam dikenal jilbab atau hijab) berhubungan dengan perintah agama, dan bahwa berhijab dikonstruksikan sebagai penunjuk keshalehan perempuan (Suhendra, 2013).

Bahkan, dari pakaian yang dianggap tidak pantas tersebut, perlakuan terhadap Salmafina yang mungkin kurang baik menjadi sah atau dibolehkan. Ini bisa dilihat dari komentar pengguna Instagram dengan akun kanaya_atikah yang telah dirujuk sebelumnya (Gambar 2). Dalam komentarnya, kanaya_atikah mengemukakan bahwa Salmafina pantas dicerai oleh suaminya karena Ia dinilai sebagai sosok yang tidak baru, dan tentu saja hal itu diukur dari cara Salmafina berpakaian dan diunggahnya di Instagram.

Penilaian yang menghubungkan cara berpakaian dengan moralitas juga dapat ditemukan dalam komentar akun dengan nama bellaandinii. Dalam komentarnya, bellaandinii menempatkan kepindahan agama Salmafina sebagai tindakan sakit hati, dan segera 
kepindahan itu mendorong Salmafina untuk membuka aurat. Dalam komentar lainnya, dinyatakan bahwa agama (dalam hal ini agama Islam) dinilai para pengguna Instagram sebagai telah "mengekang" Salmafina sehingga ketika dirinya berpindah agama dan menjadi murtad maka hijab dilepas dan kemudian berbikini. Komentar dari akun lainnya menyatakan, "aurat sal, secantik apa tubuh, sebagus apa tubuh tapi semua orang bisa melihatnya, maka tiada artinya dan murah harganya".

Gagasan bahwa pakaian merepresentasikan moralitas tidak hanya menjadi monopoli para komentator yang beragama Islam. Para komentator nonmuslim juga melakukan hal yang kurang lebih sama. Ini, misalnya, bisa dilihat dari komentar akun Instagram dengan nama novitamoniung dan nolyanasangkuadje yang mengomentari unggahan Salmafina pada 24 Oktober 2019 (Gambar 3).

Akun dengan nama novitamoniung mengungkapkan bahwa cara Salmafina dalam menampilkan dirinya melalui pakaian itulah yang membuatnya dihujat. "Inilah..." dalam kata pertama komentar tersebut yang merujuk pada unggahan Salmafina (Gambar 3) merujuk pada cara berpakaian Salmafina yang memamerkan punggungnya. Gaya hidup yang demikian (maksudnya dalam unggahan Salmafina di pantai seperti ditunjukkan pada Gambar 1 dan 3) tidak mencerminkan dan menunjukkan karakter Yesus. "Maaf...Salma belum menunjukkan karakter Yesus". Hal itu karena Salma tidak melindungi tubuh, sedangkan tubuh merupakan bait Allah yang harus dilindungi seperti ditegaskan dalam komentar tersebut.

Komentar nolyanasangkuadje bahkan menariknya dalam wacana ke-Kudus-an. Dalam pandangannya, cara berpakaian Salmafina tidak mencerminkan ke-Kudus-an, dan karena itu Salmafina tidak akan masuk ke dalam kerajaan Allah. Ini karena kerajaan Allah dalam pandangan nolyanasangkuadje mensyaratkan ke-Kudus-an, dan apa yang dilakukan Salmafina dengan pakaian beserta pameran fotonya tidak mencerminkan ke-Kudus-an yang dimaksud.
Di antara banyak pengguna yang menyerang moralitas Salmafina dari caranya berpakaian, ada pula yang menggugat moralitas yang semata disandarkan pada pakaian. Komentar akun octavia_okt berusaha membantah wacana moralitas yang semata disandarkan pada pakaian dan tubuh. Ia mengemukakan bahwa tidaklah mungkin menghakimi seseorang tanpa mempunyai pengetahuan yang memadai atas keseharian kehidupan seseorang. Artinya, octavia_okt menolak bahwa tidaklah mungkin menghakimi seseorang hanya bersandar pada pakaian yang digunakan Salmafina sebagaimana dirujuk oleh kanaya_atikah.

Pengguna lainnya menggugat bahwa manusia tidak mempunyai otoritas untuk menghakimi perilaku manusia lainnya. Dengan merujuk al Kitab, nursanti_manik mengemukakan bahwa yang mempunyai hak menghakimi (terhadap kebaikan seseorang) bukanlah manusia, tapi Tuhan. Seruan untuk tidak menghakimi juga dilakukan akun srimulyanibiyo_gifford. Ia menyerukan pentingnya untuk tidak menghakimi Salmafina karena pakaian yang digunakan, dan para komentator yang merasa telah menutup tubuhnya lebih rapat untuk menjaga komentarnya terhadap orang lain.

Dari uraian tersebut, peneliti berpendapat bahwa tubuh dan pakaian telah menjadi ruang bagi pertarungan berbagai wacana moralitas. Ada dua wacana besar yang dapat diidentifikasi dari analisis atas komentar para pengguna di akun Instagram Salmafina ketika mengunggah fotonya ketika di Bali. Jika dirujuk, ada tiga sumber wacana moral yang berkembang, yakni wacana moral yang bersumber pada agama, hati nurani, dan juga budaya. Dari ketiga sumber wacana moral tersebut, wacana moralitas yang bersumber pada agama menjadi yang paling kuat karena menjadi rujukan baik bagi para pembela Salmafina maupun yang menentangnya. Jika merujuk pada teori fondasi moral yang menyatakan meskipun semua intuisi moral adalah aktif, tetapi senantiasa ada intuisi yang paling kuat maka tampak bahwa intuisi moral agamalah yang paling kuat (Prabhu et al., 2020: 257). 
Para pengusung wacana moralitas agama bukan hanya dari kelompok muslim, tapi juga kelompok Kristen. Agama yang dipeluk Salmafina ketika memutuskan tidak lagi menjadi muslim. Meskipun demikian, menariknya, kedua kelompok cenderung tidak menerima kehadiran Salmafina, dan justru meletakkannya sebagai "liyan".

\section{Memahami Konteks Wacana Tubuh dan Pakaian Salmafina}

Sejak kecil, manusia diajarkan nilainilai yang berkembang dalam masyarakat melalui keluarga, institusi pendidikan, dan institusi lainnya yang membentuk hati nuraninya. Dasar moralitas ini akan menjadi bahan pertimbangan tindakan individu.

Setiap tindakan manusia selalu berlangsung dalam situasi tertentu yang memungkinkannya untuk dikendalikan oleh situasi dan konteks sosial tersebut (Saukko, 2011). Ini karena tindakantindakan manusia akan dipengaruhi oleh wacanawacana tertentu yang berasal dari beragam institusi seperti agama, norma-norma sosial, dan juga hukum dalam masyarakat. Wacana mengenai moralitas dalam media sosial seperti dalam kasus Salmafina karenanya tidak dapat dilepaskan dari konteks sosial yang lebih luas.

Penelitian ini mengajukan tiga konteks yang mendasari munculnya wacana moralitas di sekitar tubuh dan pakaian yang digunakan Salmafina dalam unggahan di akun Instagram-nya, yakni liberalisasi pascaOrde, meluasnya Islam dan peranan agama dalam masyarakat Indonesia, dan media sosial.

\section{Liberalisasi Pasca-Orde Baru}

Reformasi bagaimanapun telah memberikan dasar bagi munculnya suatu situasi yang lebih bebas yang memungkinkan para anggota masyarakat untuk lebih mengekspresikan diri dalam kehidupan publik (Heryanto, 2015). Situasi ini juga memungkinkan para anggota masyarakat untuk mencari nilai-nilai baru yang mungkin bertentangan dengan nilainilai lama. Sesuatu yang tidak mungkin terjadi dalam sistem otoritarian Orde Baru yang berlangsung lebih dari 30 tahun. Liberalisasi pasca-Orde Baru juga memantik kebangkitan Islam dalam skala luas (Brenner, 2011; Heryanto, 2012, 2015). Jika pada masa Orde Baru ruang gerak Islam dibatasi, dan banyak tokohnya menjadi tahanan politik maka setelah Orde Baru jatuh, Islam (beserta kekuatan yang lain) muncul ke permukaan dan lebih bebas dalam mengekspresikan dirinya. Kekuatankekuatan ini bertarung dalam ruang publik untuk mendapatkan kendali wacana dan kekuasaan sosial dan politik. Di antara kekuatan-kekuatan itu, Islam menjadi kekuatan utama yang muncul. Ini dapat dilacak dari maraknya film-film Islam dan diadopsinya secara luas simbol-simbol Islam dalam budaya populer. Studi Paramadita (Heryanto, 2015), misalnya, menunjukkan upaya orang-orang di balik layar orang-orang industri film untuk memeluk Islam atau meningkatkan "keislaman" mereka. Kecenderungan ini juga berjalin dengan minat-minat khalayak yang sangat besar dalam menikmati tayangantayangan berbau agama di layar televisi maupun bioskop (Heryanto, 2015; Rakhmani, 2014).

\section{Konteks Islam dan Agama}

Ada dua hal yang dapat dipelajari dari kasus Salmafina Sunan, yang berhubungan di sekitar wacana moralitas dan pakaian. Pertama, agama sebagai sumber acuan utama untuk menilai moralitas diri seseorang. Ini jelas terefleksi ke dalam hampir seluruh komentar pakaian Salmafina dalam merespon unggahan bikini. Ini juga terjadi bagi "pembela" Salmafina yang menyerukan untuk tidak melakukan penghakiman terutama semata karena pakaian. Kedua, rivalitas wacana agama Islam dan Kristen. Kontestasi ini telah berlangsung lama, dan dalam beberapa kasus telah meledak menjadi konflik sosial (Bertrand, 2012; Schulze, 2017), terutama yang dimotori oleh kelompokkelompok yang dikategorikan sebagai radikal ( $a$ radical islamic group) (Hidayati \& Harder, 2020). 
Agama sebagai standar moral telah berlangsung lama dalam masyarakat Indonesia yang religius. Pelecehan agama menjadi soal yang sangat serius di Indonesia. Moralitas dan agama karenanya menjadi isu yang terus menghangat di Indonesia. Seperti ditunjukkan oleh Heryanto (2012) dalam kasus Inul Daratista, "bagi para pengritiknya, Inul merupakan lambang kerusakan dan kemerosotan moral Indonesia, dan budaya-Barat yang diikuti Indonesia". Dalam pandangan Heryanto, apa yang terjadi pada Inul merupakan ujian atas islamisasi di Indonesia. Ariel Heryanto (Heryanto, 2015) mendefinisikan Islamisasi sebagai berikut.

"Ciri khas islamisasi yang berbeda-beda ini adalah terjadinya perluasan dalam cara pandang, penampilan, dan perayaan besarbesaran terhadap unsur-unsur material dan praktik-praktik yang mudah dipahami dalam masyarakat Indonesia sebagai mengandung nilai-nilai Islami atau "yang diislamkan". Ariel Heryanto (Heryanto, 2015) lebih jauh mengemukakan bahwa "Islamisasi juga mencakup ragam yang luas dari praktikpraktik sosial dan perjuangan politik yang tak bisa disederhanakan sebagai persoalan agama atau politik agama semata". Meskipun demikian, unsur-unsur majemuk dari islamisasi mempunyai makna yang berbeda. Seseorang yang menggunakan atribut atau simbol Islam, tapi makna atasnya bisa sama sekali berbeda. Ini ditunjukkan, misalnya, dalam kajian-kajian terhadap perempuan hijab di media sosial (Baulch \& Pramiyanti, 2018; Beta, 2014; Savitri Hartono, 2018). Kajian-kajian itu menyebutkan bahwa hijab tidak semata merepresentasikan keshalehan, tapi beragam identitas seperti perempuan yang otonom dan modern. Meskipun demikian, studi tersebut menunjukkan dengan jelas bahwa, bagi perempuan, mengenakan jilbab menjadi penanda penting dari gambaran wanita "shaleh" atau setidaknya-tidaknya wanita yang ingin berhijrah (menjadi shaleh). Dalam wilayah politik, studi Dewi (2017) menemukan bahwa penggunaan hijab di antara para public figure, pemimpin kepala daerah perempuan bukan saja menghindarkannya dari gosip buruk, tapi juga membantu penerimaan publik.

Dengan merujuk studi-studi di atas, menjadi tidak mengherankan ketika unggahan bikini Salmafina memantik wacana moralitas agama. Meluasnya penggunaan simbol Islam dan praktik-praktik yang terislamkan membuat apapun yang dilakukan Salmafina terutama dalam posisinya sebagai seorang murtad (dalam terminologi Islam) akan senantiasa ditarik dari dasar moralitas agama.

Kuatnya wacana moralitas agama ini tidak hanya dimonopoli oleh para komentator beragama Islam. Para komentator beragama Kristen juga meletakkan pakaian dan tubuh sebagai jangkar moralitas. Beberapa komentator karenanya menarik ke soal ke-Kudus-an atau kesucian ketika menanggapi unggahan Salmafina yang mengunggah fotonya ketika menggunakan bikini. Pakaian dalam hal ini memegang posisi penting yang digunakan para komentator untuk menilai baik-buruk pribadi seseorang.

Dalam tradisi agama, pakaian mempunyai peran penting dalam menunjukkan ketaatan seseorang atas perintah agama. Pakaian sudah lama menjadi penanda identitas suatu agama, dan sekaligus menunjuk keshalehan. Di kalangan Islam, wacana ini jauh lebih kuat dibandingkan penganut agama lain. Jika para penganut Kristen yang berpakaian sesuai ajaran agama terbatas pada para suster, tidak demikian para penganut agama Islam. Dalam ajaran Islam, meskipun ada beberapa tafsir yang berbeda (Nuroniyah, 2019; Suhendra, 2013), tapi secara umum diakui bahwa para perempuan wajib menggunakan jilbab menggunakan jilbab atau hijab. Perintah menggunakan jilbab itu untuk menunjukkan bahwa yang bersangkutan adalah perempuan baik-baik, meninggikan kehormatan dan sekaligus menghindarkannya dari kejahatan laki-laki (Suhendra, 2013). 


\section{Konteks Media Sosial}

Konteks lain yang tidak kalah pentingnya adalah kemunculan media sosial yang saat ini digunakanolehmasyarakatsecaraluas.Adabanyak motif dan kebutuhan yang dapat diidentifikasi terhadap sifat adiktif penggunaan media sosial. Studi Raharjo, misalnya, mengidentifikasi motif orang-orang menggunakan Instagram, yakni demi kesenangan dan kebutuhan untuk menjalin pertemanan yang hangat (Rahardjo et al., 2020). Meskipun demikian, hal paling penting tentu saja adalah sifat media sosial yang memungkinkan munculnya suatu corak baru bagi komunikasi di antara individu dan kelompok. Dalam media baru seperti Facebook, Instagram, YouTube, Twitter, dan bahkan aplikasi percakapan, pengguna memiliki otonomi yang lebih besar dibandingkan dengan khalayak media massa. Seperti dikemukakan oleh Ruggiero (Baran dan Davis, 2010), sekali pesan terdigitalisasi, manipulasi media menjadi tidak dapat diukur, membuat individu memiliki lebih banyak kontrol daripada terhadap media tradisional. Ini mengandung pengertian bahwa pengguna media lebih aktif dan mempunyai kuasa yang lebih besar dibandingkan dengan khalayak media massa.

Dengan merujuk Meyrowitz (1985), Holmes (2012) mengatakan bahwa media menciptakan lingkungan dan berbagai bentuk pertemuan elektronik yang dapat memotong melalui pemisahan ruang atau kemudian menggantinya dengan versi elektronik. Dalam hal ini, dapat dikatakan bahwa keberadaan media baru yang di antaranya mewujud dalam bentuk media sosial haruslah dilihat sebagai suatu bentuk khusus di mana proses komunikasi model baru berlangsung. Seperti ditunjukkan oleh David Holmes pada bagian lainnya, bentuk-bentuk komunikasi yang termediasikan-yang dalam hal ini melalui media sosial-pada dasarnya merupakan suatu bentuk perluasan dari model komunikasi tatap-muka dengan cara lain. Jika demikian, maka interaktivitas komunikasi yang dibawa oleh media sosial harus dibaca dalam posisinya untuk memperluas komunikasi tatap muka yang terbatas. Dalam hal ini, batas antara kehadiran dan tak kehadiran menjadi kabur. Komunikasi melalui media sosial juga menciptakan suatu gejala baru dalam bentuk respon-respon yang termediasikan.

Menurut Karlina Supeli dalam suatu pidato kebudayaan pada 2013 (Supeli, 2013), teknologi digital merupakan suatu kenikmatan baru. Dalam dunia kontemporer, menurut Supeli, salah satu sumber kenikmatan terbesar berasal dari teknologi digital, dan Indonesia menjadi salah negara dengan pengguna media sosial terbesar, dan pengguna terbanyak adalah media sosial.

Indonesia ternyata bukan hanya sebagai salah satu pengguna media sosial terbesar di dunia, tapi sekaligus merupakan negara pengguna paling aktif. Seperti dicatat oleh Karlina Supeli, cuitan (twit) terbanyak berasal dari Jakarta. Jakarta adalah kota dengan ciap-ciap tertinggi di dunia, 15 twit/detik.

Teknologi digital telah membawa dunia baru dan budaya baru, termasuk dalam hal berkomuniaksi. Lebih jauh, Karlina Supeli (Supeli, 2013) mengatakan sebagai berikut. "Sebuah budaya baru telah lahir bersama teknologi digital. Itulah budaya selalu terhubung (always online), budaya komentar (comment culture) dan kecenderungan untuk selalu berbagi (sharing). Gejala ini membawa kita ke situasi paradoks. Perlu disadari bahwa masalah-masalah yang mendera semakin membutuhkan pemikiran yang mendalam, "kita menciptakan budaya berkomunikasi yang justru mengurangi waktu kita untuk berpikir tanpa tersela ... di bawah godaan untuk segera melontar komentar ... kita tidak lagi punya cukup waktu untuk memikirkan problem-problem yang rumit," tulis seorang peneliti media sosial Sherry Turkle.20 Hasrat untuk segera berkomentar atau menyimak komentar orang lain tentang kita, menjadikan kita mahluk pauseable, bisa dijeda, seperti tape atau video recorder". Pengamatan Karlina Supeli di atas kiranya meneguhkan hasil penelitian ini. Partisipasi aktif para komentator media sosial dalam menanggapi 
masalah-masalah yang muncul dalam kasus Salmafina merefleksikan suatu budaya baru, komunikasi cepat menghilangkan waktu atau jeda untuk berusaha merefleksikan komentarkomentarnya. Ketika hal itu berhubungan dengan moralitas, respon pengguna dalam memberi komentar pada unggahan Salmafina menjadi lebih cepat. Ini ditunjukkan dari banyaknya komentar di Instagram yang mencapai ratusan beberapa jam setelah fotonya berbikini diunggah.

Mereka menjadi kurang peduli bahwa komentar itu tertuju pada dimensi hakiki Salmafina dalam jati dirinya sebagai manusia. Suatu entitas yang kompleks yang menampilkan bukan hanya tampilan fisik terlebih dalam cara berpakaian atau karena mempersoalkan sesuatu yang menurut para komentator tidak penting. Identitas Salmafina tidak dapat ditentukan dari cara berpakaian sebagaimana terefleksi dalam beberapa wacana yang dimunculkan dari para komentator. Kajian ini juga menunjukkan bahwa ruang ekspresi bebas yang ditawarkan media sosial tampaknya digunakan dengan sangat baik dari para pengguna media sosial dengan antusiasme untuk berpartisipasi aktif. Namun hal itu kurang dilandasi suatu budaya literer yang baik. Akibatnya, kehadiran media sosial di Indonesia dengan merujuk pada kasus Salmafina hanya memindah suatu tradisi budaya lisan dalam bentuk yang baru. Jika budaya lisan mewujud dalam ekspresi lisan (seperti tercermin dalam komunikasi tatap muka), maka budaya komunikasi dalam konteks media sosial hanya berubah bentuknya. Komunikasi dilakukan melalui tulis, tapi nalarnya tetap dalam bingkai nalar lisan minus kehadiran.

\section{Simpulan}

Penelitian ini menunjukkan bahwa unggahan Salmafina ketika di Bali terutama ketika menggunakan bikini telah memantik beragam wacana moralitas. Wacana moralitas ini bersaing dan berkisar di seputar unggahan Salmafina yang menggunakan pakaian bikini. Dengan kata lain, baik buruknya pribadi Salmafina diukur dari tubuh dan caranya berpakaian.
Wacana-wacana yang berasal dari para pengguna itu berasal dari sumber-sumber moralitas yang beragam. Wacana moralitas yang bersumber dari agama menjadi yang paling kuat disuarakan oleh para pengguna. Ini tidak hanya disuarakan oleh para penentang Salmafina dari kelompok muslim, tapi juga Kristen. Agama yang dipeluk Salmafina setelah memutuskan tidak lagi menganut agama Islam. Hal ini telah mendorong proses "peliyanan" di antara para penentang itu terhadap sosok Salmafina. Ia tidak diterima baik oleh kelompok Islam (yang merasa dikhianati karena perpindahan agamanya), tapi juga kelompok Kristen. Meskipun begitu, ada pula wacana yang mendukung Salmafina dengan menyerukan pentingnya untuk tidak menghakimi Salmafina karena otoritas penghakiman ada pada Tuhan, dan bahwa tidaklah adil menghakimi Salmafina semata dari caranya berpakain.

Kelemahan penelitian ini karena semata didasarkan pada observasi dan analisis tekstual. Peneliti menyarankan agar dilakukan penelitian-penelitian yang lebih luas dengan menggali data bukan saja dari teks, tetapi juga wawancara mendalam sehingga isu moralitas di media sosial lebih dapat ditangkap.

Isu moralitas hampir selalu muncul dalam ruang publik di Indonesia, tapi belum banyak digali. Sifat partisipatif media sosial membuka ruang bagi kajian-kajian pengguna karena sifat tidak hadir di media sosial menciptakan komunikasi yang lebih lugas. Ini mendorong komentar-komentar yang lebih cepat dan tanpa melalui proses reflektif. Padahal, komentar itu menyangkut pribadi sehingga penting bagi para pengguna untuk mengembangkan komunikasi yang lebih etis ketika berpartisipasi di media sosial.

\section{Ucapan Terima Kasih}

Penelitian ini dibiayai oleh hibah Program Studi Ilmu Komunikasi Universitas Islam Indonesia. Penulis mengucapkan terima kasih kepada Maulida Averoes yang telah membantu mengumpulkan bahanbahan dari Instagram Salmafina Sunan. 


\section{Daftar Pustaka}

Baran, S. J., dan Davis, D. K. (2010). Teori komunikasi massa: Dasar, pergolakan, dan masa depan. Salemba Humanika.

Basevi, R., Reid, D., \& Godbold, R. (2014). Ethical guidelines and the use of social media and text messaging in health care: A review of literature. New Zealand J Physiotherapy, 42(2), 68-80.

Baulch, E., dan Pramiyanti, A. (2018). Hijabers on instagram: Using visual social media to construct the ideal muslim woman. Social Media and Society, 4(4). https://doi. org/10.1177/2056305118800308

Bertrand, J. (2012). Nasionalisme dan konflik etnis di Indonesia. Penerbit Ombak.

Beta, A. R. (2014). Hijabers: How young urban muslim women redefine themselves in Indonesia. International Communication Gazette, 76(4-5), 377-389. https://doi. org/10.1177/1748048514524103

Boddy, J., dan Dominelli, L. (2017). Social media and social work: The challenges of a new ethical space. Australian Social Work, 70(2), 172-184. https://doi.org/10.1080/031 2407X.2016.1224907

Brenner, S. (2011). Private moralities in the public sphere: Democratization, Islam, and gender in Indonesia. American Anthropologist, 113(3), 478-490. https://doi.org/10.1111/ j.1548-1433.2010.01355.x

Dewi, K. H. (2017). Piety and sexuality in a public sphere: Experiences of javanese muslim women's political leadership. Asian Journal of Women's Studies, 23(3), 340-362. https://doi.org/10.1080/12259276.2017.135 2250

Eagleton, T. (2016). The idea of culture: Manipulasi-manipulasi kebudayaan (A. N. Zaman (ed.)). INDeS Publishing.

Fitransyah, R. R., dan Waliyanti, E. (2018). Perilaku cyberbullying dengan media Instagram pada remaja di Yogyakarta. Indonesian Journal of Nursing Practice, 2(1), 36-48. https://doi.org/10.18196/ ijnp. 2177
Furedi, F. (2016). Moral panic and reading: Early elite anxieties about the media effect. Cultural Sociology, 10(4), 523-537. https:// doi.org/10.1177/1749975515626953

Haris, M. (2019). Diskursus etika religius: Perspektif Nurcholish Madjid dan Franz Magnis-Suseno. Pustaka Pelajar.

Hayes, P., dan Kelly, S. (2018). Distributed morality, privacy, and social media in natural disaster response. Technology in Society. https://doi.org/10.1016/j. techsoc.2018.05.003

Heryanto, A. (2012). Budaya pop dan persaingan identitas. In A. Heryanto (Ed.), Budaya Populer di Indonesia, Mencairnya Identitas Pasca-Orde Baru. Jalasutra.

Heryanto, A. (2015). Identitas dan kenikmatan, politik budaya layar di Indonesia (1st ed.). KPG.

Hidayati, M., dan Harder, N. V. D. (2020). 'I love Jesus because Jesus is Muslim': Inter- and intra-faith debates and political dynamics in Indonesia. Islam and Christian-Muslim Relations, 31(2), 173-190. https://doi.org/1 0.1080/09596410.2020.1780389

Holmes, D. (2012). Teori komunikasi media, teknologi dan masyarakat (T. Radike (ed.); Pertama).

Hunt, A. (1997). ' Moral panic ' and moral language in the media. The British Journal of Sociology, 48(4), 629-648.

Indrayani, S. ., dan Johansari, C. A. (2019). Cyberbullying use on teenage artists and its implications. Litera, 18, 275-296.

Kimball, E., \& Kim, J. (2013). Virtual boundaries: Ethical considerations for use of social media in social work. In Source: Social Work (Vol. 58, Issue 2). https://www. jstor.org/stable/23719787

Kozinetz, R. V. (2010). Netnography, doing etnographic research online, Los Angeles, London, New Delhi, Singapoare. In SAGE Publications. SAGE Publications. 
Lacey, N. (2002). Media, institutions and audiences key concepts in media studies (2nd ed.). Red Globe Press.

Lister, M., Dovey, J., Giddings, S., Grant, I., dan Kelly, K. (2009). New media: A critical introduction. Routledge.

Mahanani, P. A. R. (2017). Urgensi pemahaman etika komunikasi Islami pada mahasiswa perguruan tinggi Agama Islam dalam mengurangi dampak negatif penggunaan Facebook. Jurnal ASPIKOM, 2(2), 127. https://doi.org/10.24329/aspikom.v2i2.65

Nasrullah, R. (2017). Media sosial: Perspektif komunikasi, budaya, dan sosioteknologi. Simbiosa Rekatama Media.

Nuroniyah, W. (2019). Rethinking hijab in contemporary Indonesia: A study of hijab community "Tuneeca lover community." Wawasan: Jurnal Ilmiah Agama Dan Sosial Budaya, 4(2), 214-221. https://doi. org/10.15575/jw.v4i2.5643

Pamungkas, A. S. (2018). Mediatisasi dakwah, moralitas publik dan komodifikasi Islam di era neoliberalisme. Maarif, 13(1), 55-75. https://doi.org/10.47651/mrf.v13i1.12

Prabhu, S., Hahn, L., Tamborini, R., \& Grizzard, M. (2020). Do morals featured in media content correspond with moral intuitions in media users?: A test of the MIME in two cultures. Journal of Broadcasting and Electronic Media, 64(2), 255-276. https:// doi.org/10.1080/08838151.2020.1757364

Prihantoro, E., Damintana, K. P. I., dan Ohorella, N. R. (2020). Self disclosure generasi milenial melalui second account Instagram. Jurnal Ilmu Komunikasi, 18(3), 312. https:// doi.org/10.31315/jik.v18i3.3919

Rahardjo, W., Qomariyah, N., Andriani, I., Hermita, M., \& Zanah, F. N. (2020). Adiksi media sosial pada remaja pengguna Instagram dan WhatsApp: Memahami peran need fulfillment dan social media engagement. Jurnal Psikologi Sosial, 18(1), 5-16. https://doi.org/10.7454/jps.2020.03
Rakhmani, I. (2014). Mainstream islam: Television industry practice and trends in Indonesian sinetron. In Asian Journal of Social Science (Vol. 42, Issues 3-4). https:// doi.org/10.1163/15685314-04203009

Rao, N., dan Lingam, L. (2020). Smartphones, youth and moral panics: Exploring print and online media narratives in India. Mobile Media and Communication. https://doi. org/10.1177/2050157920922262

Rizal, A. (2021). Rata-rata orang Indonesia habiskan tiga jam untuk main media sosial. Infokomputer.Grid.Id. https://infokomputer. grid.id/read/122572616/rata-rata-orangindonesia-habiskan-3-jam-untuk-mainmedia-sosial

Saukko, P. (2003). Doing Research in Cultural Studies: An Introduction to Classical and New Methodological Approaches. SAGE Publications.

Saukko, P. (2011). Doing research in cultural studies. Doing Research in Cultural Studies. https://doi.org/10.4135/9781849209021

Savitri Hartono, H. (2018). Virtually (Im)moral: Pious Indonesian Muslim Women's Use of Facebook. Asian Studies Review, 42(1), 3952. https://doi.org/10.1080/10357823.2017. 1407290

Schulze, K. E. (2017). The "ethnic" in Indonesia's communal conflicts: violence in Ambon, Poso, and Sambas. Ethnic and Racial Studies, 40(12), 2096-2114. https:// doi.org/10.1080/01419870.2017.1277030

Sosiawan, E. A., dan Wibowo, R. (2020). Kontestasi berita hoax pemilu Presiden tahun 2019 di media daring dan media sosial. Jurnal Ilmu Komunikasi, 17(2), 133. https:// doi.org/10.31315/jik.v17i2.3695

Sugiyono dan Lestari, P. (2021). Metode penelitian komunikasi (Kuantitatif, kualitatif, dan cara mudah menulis artikel pada Jurnal Internasional). Alfabeta.

Suhendra, A. (2013). Kontestasi identitas melalui pergeseran interpretasi hijab dan jilbab dalam Al Qur'an. Palastren, 6(1), 1-22. 
Supeli, K. (2013). Kebudayaan dan kegagapan kita. http://aikon.org/wp-content/ uploads/2019/11/Karlina_Supelli___Pidato Kebudayaan_TIM_11-11-20131.pdf

Tamborini, R., Eden,A., Bowman, N.D., Grizzard, M., Weber, R., dan Lewis, R. J. (2013). Predicting media appeal from instinctive moral values. Mass Communication and Society, 16(3), 325-346. https://doi.org/10.1 080/15205436.2012.703285

Tester, K. (1994). Media, culture, and morality. Sage Pub.
Venäläinen, S., dan Virkki, T. (2019). Struggles for moral value and the reproduction of gendered and racialised hierarchies in online discussions of violence. Sociological Review, 67(6), 1367-1382. https://doi. org/10.1177/0038026119866635

Walsh, J. P. (2020). Social media and moral panics: Assessing the effects of technological change on societal reaction. International Journal of Cultural Studies, 23(6), 840-859. https://doi.org/10.1177/1367877920912257 